\title{
Skeletal and Cardiac Muscle Ergogenics and Side Effects of Clenbuterol Treatment
}

\author{
Aymeric Douillard* \\ INRA, UMR866 Dynamique Musculaire et Métabolisme, Université Montpellier 1, F-34060 Montpellier, France
}

\begin{abstract}
Well known, well detected and still used by athletes, clenbuterol is one of the $\beta_{2}$-agonists which has no authorization for therapeutic use, contrarily to salbutamol, salmeterol and formoterol in the 2012 World Anti-Doping Agency list. However, clenbuterol is still detected in athletes' antidoping test samples. Its ability to induce muscle hypertrophy but also its strong lipolytic action and the absence of androgenic effects have made it a prized substances by athletes, specially females, without scruples whose performance requires significant muscle strength. Like the effects of clenbuterol on the heart, the effects of clenbuterol on skeletal muscle are dependent on the doses used and duration of the treatment. If there is a consensus concerning the clenbuterol action on the phenotypic conversion from slow to fast type fibers and on the hypertrophy, there is, to our knowledge, no consensus concerning the effects of clenbuterol on the slow type fibers and slow profile muscles. There is also no consensus concerning the clenbuterol effects on performance.
\end{abstract}

We will shortly reviewing the known operating mode, side and benefits effects of short and long term $\beta$-agonists, and specially clenbuterol, treatment on mammals.

\section{Introduction}

Among the various pharmacological doping substances, the $\beta_{2}$ agonists were first used for their bronchodilatory property by smooth muscle relaxation. According to the World Anti-Doping Agency (WADA) the use of all $\beta_{2}$-agonists and their isomers $\mathrm{D}$ and $\mathrm{L}$ is banned in sport. An authorization for therapeutic use may be granted for 3 $\beta_{2}$-agonists, salbutamol, salmeterol and formoterol in an inhaled form. However, clenbuterol is placed on the banned list in the class of anabolic agents and that of $\beta$-agonists. Its ability to induce muscle hypertrophy but also its strong lipolytic action and the absence of androgenic effects have made it a prized substances by athletes, specially females, without scruples whose performance requires significant muscle strength.

The importance of the signaling pathway of $\beta_{2}$-adrenoceptors in the heart is well known today, however, only recently have we begun to understand and take into consideration the importance of this pathway in the skeletal muscle. Yet since the early 1980s, numerous studies have demonstrated the effect of $\beta_{2}$-adrenoceptors stimulation on the growth of skeletal muscle [1-15]. Although originally used to treat bronchospasm, it became apparent that some $\beta$-agonist could increase skeletal muscle mass and decrease body fat. These side effects have proven to be of interest to the livestock industry which has tried to increase the intake of animal weight and to improve meat quality, but a series of food poisoning across the Europe have led to a ban on the use of clenbuterol in animal husbandry in 1996.

The effects of $\beta$-agonists on skeletal muscle and heart, allowed us to identify potential therapeutic applications in conditions of muscle loss, attempting to mitigate or reverse the muscle wasting and weakness associated, but also trying to improve muscle growth after injury $[1,3,16,17]$. However, side effects were observed on heart and have limited the application of $\beta$-agonists and their therapeutic potential $[18,19]$. Yet these $\beta$-agonists have been repeatedly used for doping $[20,21]$, because chronic treatment leads to a phenotypic conversion to a higher fast skeletal muscle profile and a hypertrophy of muscle fibers without dependent androgenic effects.

\section{Operating Mode}

Adrenergic receptors belong to the family of guanine nucleotide binding G protein-coupled receptor (GPCR) implicated in the regulation of cardiovascular, respiratory, metabolic and reproductive functions. The $\beta$-adrenoceptors belong to the subfamily of rhodopsin receptors which also include dopaminergic, adenosine and histamine receptors $[22,23]$. These receptors are coupled to a $G$ protein composed of three subunits $(\alpha, \beta, \gamma)$. The structure of the GPCRs is composed of seven transmembrane $\alpha$-helices forming three extracellular loops, including the $\mathrm{NH} 2$ terminus and three intracellular loops including the $\mathrm{COOH}$ terminus $[24,25]$. There are three subtypes of $\beta$-adrenoceptors, $\beta_{1}, \beta_{2}$ and $\beta_{3}$ [26-29], which possess 65-70\% homology [30].

\section{Anabolic pathway}

In skeletal muscle, the proportion of $\beta_{2}$ - adrenoceptors is about $90 \%$, that of $\beta_{1}$ - adrenoceptors ranged from 7 to $10 \%$ and $\beta_{3}$ adrenoceptors are located in fat cells and in cardiac muscle [31]. In addition, $\beta$ - adrenoceptors have a higher density in slow muscles like Soleus than in fast muscles such as Extensor Digitorum Longus (EDL) [32]. However, the functional significance of this difference in density is not well understood, in fact, the response to treatment with $\beta$-agonists appears to be greater in fast muscles than in slow muscles [33,34]. This may be partly explained by the down-regulation of receptors following prolonged treatment [14].

The $\beta_{2}$-adrenoceptors bind to and $\mathrm{G} \alpha_{\mathrm{s}}$ and $\mathrm{G} \alpha_{\mathrm{i}}$ proteins [35-37] The protein $G \alpha_{i}$ is essential in the spatial localization of $G \alpha_{s}$ and in the ensuing cyclic Adenosine MonoPhosphate (cAMP) response $[38,39]$. This cAMP dependent pathway is one of the pathways responsible for hypertrophy induced by $\beta_{2}$-adrenergic stimulation in

*Corresponding author: Aymeric Douillard, INRA UMR866 DMEM 2, place Pierre Viala 34060 Montpellier, France, Tel: +33499612338; Fax: +33467545694; E-mail: aymerichpz@yahoo.fr

Received November 03, 2011; Accepted December 24, 2011; Published December 29, 2011

Citation: Douillard A (2011) Skeletal and Cardiac Muscle Ergogenics and Side Effects of Clenbuterol Treatment. J Sport Medic Doping Studie S1:001. doi:10.4172/2161-0673.S1-001

Copyright: (C) 2011 Douillard A. This is an open-access article distributed under the terms of the Creative Commons Attribution License, which permits unrestricted use, distribution, and reproduction in any medium, provided the original author and source are credited. 
skeletal muscle. In addition, the $\mathrm{G} \beta \gamma$ heterodimer is able to initiate a response independent of $\mathrm{Ga}$ subunit after $\beta_{2}$-adrenergic stimulation [40]. Indeed, the $G \beta \gamma$ dimer can activate the signaling pathway of Phosphatidylinositol 3-kinases (PI3K) [41]. PI3K is an essential protein involved in the activation of Protein Kinase B (Akt) through PIP2/PIP3 who creates two lipid binding sites to Protein Kinase B. Akt could then be phosphorylated and activated by 3'-Phosphoinositide-Dependant protein Kinase 1 (PDK). Akt is known to activate downstream effectors like Forkhead box (FoxO), Mammalian Target Of Rapamycin (mTOR), 4E binding protein 1 (4EBP1) or ribosomal protein S6 (rpS6), well known to be involved in protein synthesis, gene transcription or cell proliferation [42-44] (Figure 1).

\section{Catabolic pathway}

Some studies in the early 90 's have recorded variations in the calpain system induced by clenbuterol treatment. Calpains are $\mathrm{Ca}^{2+}-$ dependent cysteine proteases that constitute a large and diverse family. Skeletal muscle fibers contain ubiquitous calpain 1 and 2 but also calpain 3 (p94) which has, since recently, been described as a muscle-specific calpain [45-47]. Calpastatin is the endogenous protein that specifically inhibits the proteolytic activity of calpains including both calpains 1 and 2 [48]. However, the activity of ubiquitous calpains depends on many factors other than calpastatin, such as $\mathrm{Ca}^{2+}$ concentration, autolysis, intracellular localization and, although not yet clearly defined, by phosphorylation [49]. The precise roles and normal regulation of calpains in skeletal muscle are currently unclear, although they are likely to be involved in cytoskeleton organization, the cell cycle and apoptosis [48]. Calpains can degrade cytoskeletal and myofibrillar proteins $[50,51]$ but are mostly involved in limited proteolysis of some specific target proteins [48]. Several studies reported that calpains are involved in skeletal muscle remodelling and atrophy.

In skeletal muscle, a decrease in calpain 1 activity along with an increased calpain 2 and calpastatin activities/expression follow chronic high doses of clenbuterol [52,53]. Recently, we show that 21 days of clenbuterol treatment induced an early activation of the skeletal muscle calpain system as judged by the increased calpains' activity and calpain 2 autolysis that occur both in fast and slow muscles $12 \mathrm{~h}$ after the first injection [5]. The catabolic pathway of ubiquitin proteasome seems

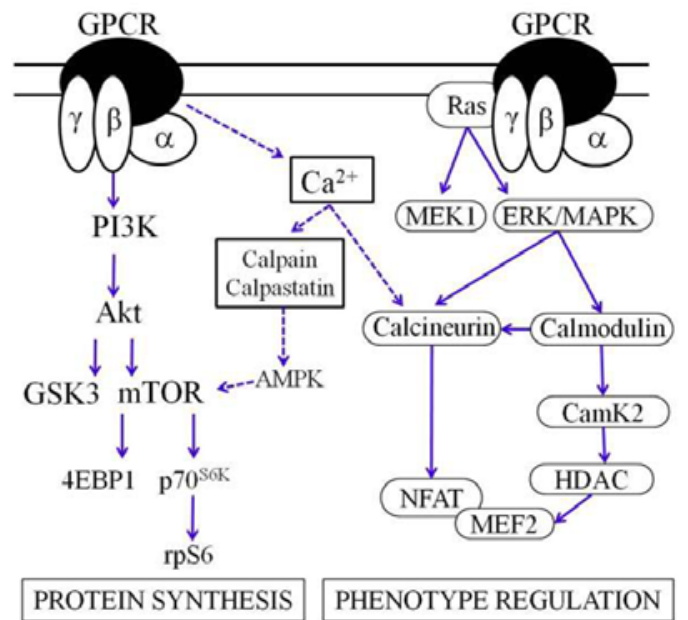

Arrows represent action (activation or inhibition) on downstream effectors. Figure 1: Signaling pathways probably involved in clenbuterol induced muscle hypertrophy and phenotypical shift. to be also involved in hypertrophic process under clenbuterol action. Indeed, Yimlamai et al. has shown that rats treated with clenbuterol had a reduced ubiquitin-proteasome activity in an Insulin Growth Factor (IGF-1) independent manner [54]. Hence, there is, to our knowledge, no consensus concerning the importance of the catabolic pathway in the clenbuterol induce muscle remodelling.

\section{Main Effects and Applications}

The primary effect of clenbuterol is a relaxation of smooth muscle causing bronchodilation. However, the use of $\beta$-agonists in the breeding industry has highlighted many side effects. Following treatment with clenbuterol, the main findings reported are the increase in lean body mass, decreased fat mass and thus increasing the ratio lean mass/fat mass. There is also a phenotypic conversion of slow fibers to fast fibers but also hypertrophy of muscle fibers that is dependent on muscle studied and the type of fiber. We observe, finally, abnormalities of calcium homeostasis during treatment with $\beta$-adrenergic including reducing sarcoplasmic reticulum $\mathrm{Ca}^{2+}$ loading in the EDL and Soleus muscles induced by an increase in the liability release $[55,56]$.

\section{Increase in mass ratio lean / fat mass}

Studies in the breeding industry showed that after a treatment with a $\beta$-agonist an increase in lean mass concomitant with a decrease in body fat of treated animals compared to control animals was observed [57-67]. Several studies in humans and animals, showed a strong lipolytic effect resulting especially from the thermogenic properties of the $\beta$-agonist $[65,68-75]$. Adipose tissue is a major site for both thermogenesis and of course for the storage of fat. The $\beta$-agonists, including clenbuterol, act on receptors of this tissue to increase lipolysis [76]. Precisely on small animal and specifically with clenbuterol, there is a $36 \mathrm{~g}$ increase in mass of Wistar rats after treatment for one week $\left(250 \mu \mathrm{g} \cdot \mathrm{kg}^{-1} \cdot \mathrm{d}^{-1}\right)$ while rats receiving placebo treatment have had an increase of $18 \mathrm{~g}$ [11]. Another study reported that treatment $(1 \mathrm{mg} . \mathrm{kg}$. ${ }^{1} \mathrm{~d}^{-1}$ ) for 15 days increases by $9 \%$ the weight of the rats while reducing (4\%) the food intake [77]. Furthermore, treatment (1.5 mg.kg. $\left.{ }^{-1} \mathrm{~d}^{-1}\right)$ for 3 weeks increases skeletal muscle mass, in an age dependent manner: the more the rats are young, the more the skeletal muscle mass increase is important. Hence, for 3 months old rats, the skeletal muscle mass compared to the total mass represents $22 \%$ of control rats and $39 \%$ of clenbuterol treated rats, whereas the same treatment for 3 weeks in for 23 months old rats, the skeletal muscle mass compared to the total mass represent $22 \%$ in the control rats and $25 \%$ of the clenbuterol treated rats [3].

\section{Cardiac muscle}

Effects when taking acute: Various studies have examined the dose-dependent responses in the heart following acute treatment with clenbuterol. It should be noted studies from Burniston et al. [78] which suggested a deleterious effect of clenbuterol on cardiomyocytes at doses between $0.01 \mathrm{mg} \cdot \mathrm{kg}^{-1}$ and $5 \mathrm{mg} \cdot \mathrm{kg}^{-1}$. Indeed, at these doses, their studies show an onset of necrosis of cardiac muscle fibers in endocardial left ventricle. It is important to note here the difference between necrosis and apoptosis. Indeed, there are two phenomena of cell death. On the one hand, necrosis is the premature cell death; it can be caused by external factors such as infection or administration of toxins (poisonous bite of an animal for example). On the other hand, apoptosis is the programmed cell death. It is the process by which cells trigger their destruction in response to a signal [79]. Unlike necrosis, apoptosis does not induce inflammation and cell membranes are not destroyed. At an injection of clenbuterol at a dose of $0.01 \mathrm{mg} \cdot \mathrm{kg}^{-1}$, necrosis reaches about 
$4 \%$ fibers [80] and nearly $8 \%$ of the fibers with the administration of larger doses $\left(5 \mathrm{mg} \cdot \mathrm{kg}^{-1}\right)$. The same study shows that the peak of necrosis of cardiac fibers is reached between 12 to 15 hours after administration of clenbuterol. Another more recent study [81] shows a time effect and dose-dependent apoptotic-necrotic reactions. Indeed, apoptotic phenomena, demonstrated immunohistochemically by an antibody directed against a marker of apoptosis, the caspase 3, appear less than an hour after the subcutaneous injection of clenbuterol at doses between $1 \mathrm{mg} . \mathrm{kg}^{-1}$ and $5 \mathrm{mg} . \mathrm{kg}^{-1}$. This apoptotic phenomenon reached a peak 4 hours after injection. However, the number of apoptotic cells is limited and does not exceed $0.8 \%$ of the total area studied. In the same study, the phenomena of necrosis, revealed by an antibody against myosin and injected intraperitoneally one hour before the injection of clenbuterol, appear 3-4 hours after injection at doses between 100 $\mu \mathrm{g} . \mathrm{kg}^{-1}$ and $5 \mathrm{mg} \cdot \mathrm{kg}^{-1}$. This phenomenon reached its peak of necrosis 12 hours after injection as shown in the first study. These results suggest a rapid implementation of processes for the destruction of heart muscle cells.

Effects of chronic intake: Many studies have investigated the possible effect of chronic treatment for several days on the heart muscle. In a first study, Emery et al. [6] observed no effect of clenbuterol ( $\left.2 \mathrm{mg} . \mathrm{kg}^{-1}{ }^{-1}{ }^{-1}\right)$ after one week of treatment on the mass of the heart muscle. Similarly, according to a study by MacLennan and Edwards, one week of treatment with clenbuterol did not significantly increase the mass of the heart in rats [11]. However, in this study, doses of clenbuterol injected remained low $\left(250 \mu \mathrm{g} \cdot \mathrm{kg}^{-1} \cdot \mathrm{d}^{-1}\right)$ compared to other studies. Indeed, Choo et al. observed in their study, after 4 days of treatment ( $4 \mathrm{mg} \cdot \mathrm{kg}^{-1} \mathrm{~d}^{-1}$ ), an increase of $12 \%$ of the mass of the heart [4]. Equivalently, treatment of $2 \mathrm{mg} \cdot \mathrm{kg}^{-1} \mathrm{~d}^{-1}$ causes an increase of 18 to $20 \%$ of cardiac mass after 2 and 5 weeks of treatment [82]. Clenbuterol is an agent that can induce cardiac hypertrophy, but it seems necessary to apply, to observe that hypertrophy, a treatment with high doses or long treatment [14,33,83-85]. However, the prolonged administration appears to have toxic effects on the heart $[19,86]$. Duncan et al. [87] have particularly highlighted the infiltration of collagen in the heart of rats treated with clenbuterol. This appearance of collagen could be related with phenomenon such as apoptosis, necrosis and inflammation described by Burniston that may precede the infiltration of collagen [80]. High doses of clenbuterol $\left(2 \mathrm{mg} . \mathrm{kg}^{-1} \mathrm{~d}^{-1}\right)$ administered for several months induced a strong left ventricular hypertrophy, but also infiltration of collagen and mechanical damage such as reducing the pressure in the left ventricle $[87,88]$. However, $\beta$-As have beneficial effects on the heart as they have been used to treat patients after a heart attack to limit or counteractatrophy $[82,89,90]$.

The effects of $\beta$-agonists on the heart are dependent on dose and duration of treatment. Thus, to observe cardiac hypertrophy treated with high dose over several weeks seems necessary. However, the deleterious effects of high doses taken in acute or chronic treatment (necrosis, infiltration of collagen) limit the therapeutic uses of these $\beta$-agonists.

\section{Skeletal muscle}

As we have seen previously, clenbuterol induced an increase in skeletal muscle mass during treatment. Two phenomena are responsible for this increase in mass, the phenotypic conversion of muscle fibers towards a faster profile and hypertrophy.

Effects of clenbuterol on the phenotypic conversion: During prolonged treatment with clenbuterol, there is a phenotypic conversion to a faster profile of skeletal muscle. Chronic administration of clenbuterol to rats or mice leads to a transition from slow (type I) to fast (type II) muscle fibers [1,57,91-95]. In addition, the phenotypic conversion is also observed among the fast fibers, from type IIa fibers to type IIx fibers or fiber type IIb [93]. This transition towards a more glycolytic profile is not only metabolic (glycolytic or oxidative) but also structural with changes in the MHC isoform composition and therefore in the contractile properties of the muscle [96]. These phenotypic changes usually occur during muscle development [97], following a protocol of electrical stimulation at high frequencies [98] during denervation or hormonal changes [99], while reducing load during a simulated loss of gravity during muscle regeneration [7] and in a more limited manner following a training protocol [100,101].

The mechanisms that control the phenotype of slow muscle fibers were studied and some signaling pathways have been described, including many factors such as calcineurin and Nuclear Factor of Activated T-cells (NFAT) [102,103], $\mathrm{Ca}^{2+} /$ calmodulin dependant kinase (CamK) [104], the Peroxisome proliferator-activated receptor Gamma Coactivator 1 (PGC1 a pathway) [105] and that of Peroxisome Proliferator-Activated Receptor $\delta$ (PPAR- $\delta$ ) [106] or Ras [107]. However, the mechanisms controlling the expression of a fast muscle phenotype are less known. A work by Grifone et al. [108] suggest that the binding of Sixl to the cofactor Eyal exerts a transcriptional regulation of the expression of fast MHC. The complex Six1/Eya1 would bind to MEF3 to induce expression of MHC proteins quickly. Indeed, when cotransfecting plasmids of Six 1 and Eyal by electroporation in the soleus muscle of mice, it was observed a phenotypic conversion of slow fibers I and IIa to faster IIb fibers. Recent data from Richard \& Maire, shows that absence of Six 1 and Six 4 leads to the development of dorsal myofibers lacking expression of fast-type muscle genes indicating a probable implication of Six 1 and Six 4 in the regulation of fast-twitch MHC [109]. However, even if the administration of clenbuterol produces a similar effect, no study has, for now, highlighted an influence of the clenbuterol on the expression levels of Six1 and Eya1 in the skeletal muscle.

Effects of clenbuterol on hypertrophy: As discussed above, chronic treatment with clenbuterol leads to increased skeletal muscle mass. This increase in mass is treated as a pure muscle cell hypertrophy [110] because hyperplasia is not associated with increased protein [93] Other $\beta_{2}$-agonists such as cimaterol, salbutamol or isoproterenol induce hypertrophy, but when administered at high doses, clenbuterol is one of the most effective agents for inducing hypertrophy. The ability of clenbuterol to induce muscle protein synthesis $[4,6,12,65,66,111,112]$ and reduce protein degradation [12,65,93,113-115] was the basis of demonstration of its anabolic power. However, there is no consensus on a preferential mechanism responsible for this clenbuterol induced hypertrophy. A more recent study highlights the ability of clenbuterol to activate the signaling pathway Akt/mTOR highlighting the fact that clenbuterol is responsible for both a decrease in protein degradation and increased protein synthesis [116]. On the other hand, the study of Shi et al. suggests that the Mitogen-Activated Protein Kinase (MAPK) signaling pathway is involved in hypertrophy induced by clenbuterol [117]. The same study shows that Extracellular signal-Regulated Kinase (ERK) is differently regulated between the fast muscles and the slow muscles. Indeed, following treatment with clenbuterol, ERK activity in the soleus is increased by $39 \%$ whereas in the Tibialis Anterior (TA) and the Gastrocnemius, there was an increase of 2.3 and 2.5 times the control levels of the ERK activity.

It should be noted that the effects of clenbuterol are different depending on the species and it seems that the effects in humans are 
less pronounced than in the farmed species. Moreover, the effects within a species vary depending on the tissue, mainly because of the density and distribution of different subtypes of receptors for a given tissue and species $[118,119]$.

The administration of $\beta_{2}$-As leads to hypertrophy of type I fibers $[57,94,120]$ and type II fibers $[15,64]$, but some studies show a similar increase in the size section of different types of fibers [121,122]. Here again, consensus does not exist. However, the disparity in species and age of animals at the beginning of treatment, the $\beta$-agonist used and the doses, route of administration, frequency and duration of treatment does not favor the establishment of a consensus.

Effects of clenbuterol on performance: Spann and Winter showed that low doses of clenbuterol don't improve performances [123]. Contrary to them, studies reported that large doses of clenbuterol (1 mg.kg. ${ }^{-1} \mathrm{~d}^{-1} / 2 \mathrm{mg} \cdot \mathrm{kg}^{-1} \mathrm{~d}^{-1}$ ) could have deleterious effects on rats' performances. Indeed, mice treated with clenbuterol for 8 weeks (1.6 mg.kg. $\left.{ }^{-1} \mathrm{~d}^{-1}\right)$ and submitted to interval training showed a reduction in total work performance $(-25 \%)$ at a run-to-exhaustion treadmill test [124]. Similarly, a treatment period of 14 weeks $\left(2 \mathrm{mg} \cdot \mathrm{kg}^{-1} \mathrm{~d}^{-1}\right)$ with clenbuterol induced a $50 \%$ decrease in swimming time to exhaustion a $57 \%$ decrease of voluntary running time and a $43 \%$ decrease of speed running [87]. These data suggests that a long clenbuterol treatment could decrease performances by earlier exhaustion.

According to Duncan, the limitations of oxidative capacity induced by $\beta_{2}$-agonists, the decrease in blood flow and cardiac muscle alterations structure are responsible for this decrease in performance [87,124]. Localized collagen infiltration in the left ventricular and increase cardiac mass could have contributed to the overall decrease in exercise training performance. Moreover, as shown previously, clenbuterol is responsible for phenotypic conversion from slow to fast skeletal muscle fibers. This conversion and therefore the greater proportion of fast fibers induces a greater velocity of shortening/contraction $[15,125]$ which could make the muscles less resistant to fatigue [125]. Torgan and colleagues reported that the metabolic phenotype is also modified by clenbuterol treatment in rats. In this study, clenbuterol was responsible for a reduction of muscle oxidative potential by reducing the Citrate Synthase (CS) activity in fast muscle (plantaris, white gastrocnemmius) and this decrease could be minimized by endurance training [126]. Mounier et al. also reported in EDL that strength training seemed to counteract, to some extent, the molecular modifications induced by chronic clenbuterol administration [127]. According to this study, a $2 \mathrm{mg} . \mathrm{kg} \cdot{ }^{-1} \mathrm{~d}^{-1}$ clenbuterol treatment improved activities of PhosphoGlycerate Kinase (PGK) and enolase but decreased PhosphoFructoKinase (PFK) and CS activity. Thus, the activity of some oxidative enzymes is decreased following treatment with clenbuterol whereas the activity of glycolytic enzymes is improved by clenbuterol [126,128-130].

However, isometric force from trained rats treated with clenbuterol (8 weeks to 2 mg.kg. ${ }^{-1} \mathrm{~d}^{-1}$ ) is increased compared to trained rats who received no additional treatment [131]. Moreover, clenbuterol is able to induce an increase in the maximum tension evoked without any muscle hypertrophy [15]. Although, clenbuterol induced hypertrophy strength gain relative to muscle mass is no more significant. Indeed, the absolute maximum force is enhanced by clenbuterol while the force relative to muscle mass is unchanged $[10,33,125]$.

\section{Conclusion}

Like the effects of clenbuterol on the heart, the effects of clenbuterol on skeletal muscle are dependent on the doses used and duration of the treatment. If the consensus is established on the action of clenbuterol on the phenotypic conversion from slow to fast type fibers and on the hypertrophy, all studies do not meet on the effects of clenbuterol on the slow type fibers and muscles with a slow profile. Thus, it seems clear that the phenotypic conversion occurs in all types of muscle from slow fibers to fast fibers, the speed and the intensity of the shift are not found in identical form in all studies. Similarly, if hypertrophy of fast fibers in all types of muscles is generally found, hypertrophy of type I fibers is one more time highly dependent on the dose used, the duration of the treatment and the type of muscle studied.

Regarding the performance, clenbuterol does not seem so interesting for athletes. As expected, if the effects on endurance performance are negative, the effects on strength or power performance are not necessarily beneficial. Thus, if the maximum speed limit is decreased, the force appears to be enhanced when the hypertrophy is not yet present. When hypertrophy is present, the absolute strength is increased and the relative strength of muscle weight is on her diminished. More work is needed to understand the mechanisms of clenbuterol action and fight more efficiently doping.

\section{References}

1. Agbenyega ET, Morton RH, Hatton PA, Wareham AC (1995) Effect of the beta 2-adrenergic agonist clenbuterol on the growth of fast- and slow-twitch skeletal muscle of the dystrophic (C57BL6J dy2J/dy2J) mouse. Comp Biochem Physiol C Pharmacol Toxicol Endocrinol 111: 397-403.

2. Beitzel F, Gregorevic P, Ryall JG, Plant DR, Sillence MN, et al. (2004) Beta2 adrenoceptor agonist fenoterol enhances functional repair of regenerating rat skeletal muscle after injury. J Appl Physiol 96: 1385-1392.

3. Carter WJ, Dang AQ, Faas FH, Lynch ME (1991) Effects of clenbuterol on skeletal muscle mass, body composition, and recovery from surgical stress in senescent rats. Metabolism 40: 855-860.

4. Choo JJ, Horan MA, Little RA, Rothwell NJ (1992) Anabolic effects of clenbuterol on skeletal muscle are mediated by beta 2-adrenoceptor activation. Am J Physiol 263: E50-56.

5. Douillard A, Galbes O, Rossano B, Vernus B, Bonnieu A, et al. (2011) Time course in calpain activity and autolysis in slow and fast skeletal muscle during clenbuterol treatment. Can J Physiol Pharmacol 89: 117-125.

6. Emery PW, Rothwell NJ, Stock MJ, Winter PD (1984) Chronic effects of beta 2-adrenergic agonists on body composition and protein synthesis in the rat. Biosci Rep 4: 83-91.

7. Gregorevic P, Plant DR, Stupka N, Lynch GS (2004) Changes in contractile activation characteristics of rat fast and slow skeletal muscle fibres during regeneration. J Physiol 558: 549-560.

8. Hinkle RT, Hodge KM, Cody DB, Sheldon RJ, Kobilka BK, et al. (2002) Skeleta muscle hypertrophy and anti-atrophy effects of clenbuterol are mediated by the beta2-adrenergic receptor. Muscle Nerve 25: 729-734.

9. Kissel JT, McDermott MP, Natarajan R, Mendell JR, Pandya S, et al. (1998) Pilot trial of albuterol in facioscapulohumeral muscular dystrophy. FSH-DY Group. Neurology 50: 1402-1406.

10. Lynch GS, Hinkle RT, Faulkner JA (1999) Year-long clenbuterol treatment of mice increases mass, but not specific force or normalized power, of skeletal muscles. Clin Exp Pharmacol Physiol 26: 117-120.

11. MacLennan PA, Edwards RH (1989) Effects of clenbuterol and propranolol on muscle mass. Evidence that clenbuterol stimulates muscle beta-adrenoceptors to induce hypertrophy. Biochem J 264: 573-579.

12. Maltin CA, Hay SM, Delday MI, Smith FG, Lobley GE, et al. (1987) Clenbuterol, a beta agonist, induces growth in innervated and denervated rat soleus muscle via apparently different mechanisms. Biosci Rep 7: 525-532.

13. McElligott MA, Mulder JE, Chaung LY, Barreto A (1987) Clenbuterol-induced muscle growth: investigation of possible mediation by insulin. Am J Physiol 253: E370-375.

14. Ryall JG, Plant DR, Gregorevic P, Sillence MN, Lynch GS (2004) Beta 2-agonist administration reverses muscle wasting and improves muscle function in aged rats. J Physiol 555: 175-188. 
Citation: Douillard A (2011) Skeletal and Cardiac Muscle Ergogenics and Side Effects of Clenbuterol Treatment. J Sport Medic Doping Studie S1:001. doi:10.4172/2161-0673.S1-001

Page 5 of 7

15. Zeman RJ, Ludemann R, Easton TG, Etlinger JD (1988) Slow to fast alterations in skeletal muscle fibers caused by clenbuterol, a beta 2-receptor agonist. Am J Physiol 254: E726-732.

16. Agrawal S, Thakur P, Katoch SS (2003) Beta adrenoceptor agonists, clenbuterol, and isoproterenol retard denervation atrophy in rat gastrocnemius muscle: use of 3-methylhistidine as a marker of myofibrillar degeneration. Jpn J Physiol 53: 229-237.

17. Busquets S, Figueras MT, Fuster G, Almendro V, Moore-Carrasco R, et al. (2004) Anticachectic effects of formoterol: a drug for potential treatment of muscle wasting. Cancer Res 64: 6725-6731.

18. Abramson MJ, Walters J, Walters EH (2003) Adverse effects of beta-agonists: are they clinically relevant? Am J Respir Med 2: 287-297.

19. Au DH, Lemaitre RN, Curtis JR, Smith NL, Psaty BM (2000) The risk of myocardial infarction associated with inhaled beta-adrenoceptor agonists. Am J Respir Crit Care Med 161: 827-830.

20. Clarkson PM, Thompson HS (1997) Drugs and sport. Research findings and limitations. Sports Med 24: 366-384

21. Delbeke FT, Desmet N, Debackere M (1995) The abuse of doping agents in competing body builders in Flanders (1988-1993). Int J Sports Med 16: 66-70.

22. Fredriksson R, Lagerstrom MC, Lundin LG, Schioth HB (2003) The G-proteincoupled receptors in the human genome form five main families. Phylogenetic analysis, paralogon groups, and fingerprints. Mol Pharmacol 63: 1256-1272.

23. Strosberg AD (1990) Biotechnology of beta-adrenergic receptors. Mo Neurobiol 4: 211-250.

24. Johnson M (2006) Molecular mechanisms of beta(2)-adrenergic receptor function, response, and regulation. J Allergy Clin Immunol 117: 18-24

25. Morris AJ, Malbon CC (1999) Physiological regulation of G protein-linked signaling. Physiol Rev 79: 1373-1430.

26. Dixon RA, Kobilka BK, Strader DJ, Benovic JL, Dohlman HG, et al. (1986) Cloning of the gene and cDNA for mammalian beta-adrenergic receptor and homology with rhodopsin. Nature 321: 75-79.

27. Emorine LJ, Marullo S, Briend-Sutren MM, Patey G, Tate K, et al. (1989) Molecular characterization of the human beta 3-adrenergic receptor. Science 245: 1118-1121.

28. Frielle T, Collins S, Daniel KW, Caron MG, Lefkowitz RJ, et al. (1987) Cloning of the cDNA for the human beta 1-adrenergic receptor. Proc Natl Acad Sci USA 84: 7920-7924

29. Xiang Y, Kobilka BK (2005) The B-Adrenergic Receptors: Lessons from knockouts. In: Press H, editor. The Adrenergic Receptors Totowa. p. 267-292.

30. Kobilka BK, Dixon RA, Frielle T, Dohlman HG, Bolanowski MA, et al. (1987) cDNA for the human beta 2-adrenergic receptor: a protein with multiple membrane-spanning domains and encoded by a gene whose chromosomal location is shared with that of the receptor for plateletderived growth factor. Proc Natl Acad Sci U S A 84: 46-50.

31. Lynch GS, Ryall JG (2008) Role of beta-adrenoceptor signaling in skeleta muscle: implications for muscle wasting and disease. Physiol Rev 88: 729-767.

32. Martin WH, Murphree SS, Saffitz JE (1989) Beta-adrenergic receptor distribution among muscle fiber types and resistance arterioles of white, red, and intermediate skeletal muscle. Circ Res 64: 1096-1105.

33. Ryall JG, Gregorevic P, Plant DR, Sillence MN, Lynch GS (2002) Beta 2-agonis fenoterol has greater effects on contractile function of rat skeletal muscles than clenbuterol. Am J Physiol Regul Integr Comp Physiol 283: R1386-1394.

34. Ryall JG, Sillence MN, Lynch GS (2006) Systemic administration of beta2adrenoceptor agonists, formoterol and salmeterol, elicit skeletal muscle hypertrophy in rats at micromolar doses. Br J Pharmacol 147: 587-595.

35. Gosmanov AR, Wong JA, Thomason DB (2002) Duality of G protein-coupled mechanisms for beta-adrenergic activation of NKCC activity in skeletal muscle. Am J Physiol Cell Physiol 283: C1025-1032.

36. Xiao RP, Avdonin P, Zhou YY, Cheng H, Akhter SA, et al. (1999) Coupling of beta2-adrenoceptor to $\mathrm{Gi}$ proteins and its physiological relevance in murine cardiac myocytes. Circ Res 84: 43-52.

37. Xiao RP, Cheng H, Zhou YY, Kuschel M, Lakatta EG (1999) Recent advances in cardiac beta(2)-adrenergic signal transduction. Circ Res 85: 1092-1100.

38. Chen-Izu Y, Xiao RP, Izu LT, Cheng H, Kuschel M, et al. (2000) G(i)- dependent localization of beta(2)-adrenergic receptor signaling to L-type $\mathrm{Ca}(2+)$ channels. Biophys J 79: 2547-2556.

39. Kuschel M, Zhou YY, Cheng H, Zhang SJ, Chen Y, et al. (1999) G(i) proteinmediated functional compartmentalization of cardiac beta(2)-adrenergic signaling. J Biol Chem 274: 22048-22052.

40. Yamamoto DL, Hutchinson DS, Bengtsson T (2007) Beta(2)-Adrenergic activation increases glycogen synthesis in L6 skeletal muscle cells through a signalling pathway independent of cyclic AMP. Diabetologia 50: 158-167.

41. Lopez-Ilasaca M, Crespo P, Pellici PG, Gutkind JS, Wetzker R (1997) Linkage of $G$ proteincoupled receptors to the MAPK signaling pathway through $P$ 3-kinase gamma. Science 275: 394-397.

42. Bodine SC, Stitt TN, Gonzalez M, Kline WO, Stover GL, et al. (2001) Akt/mTOR pathway is a crucial regulator of skeletal muscle hypertrophy and can prevent muscle atrophy in vivo. Nat Cell Biol 3: 1014-1019.

43. Pallafacchina G, Calabria E, Serrano AL, Kalhovde JM, Schiaffino S (2002) A protein kinase B-dependent and rapamycin-sensitive pathway controls skeletal muscle growth but not fiber type specification. Proc Natl Acad Sci U S A 99: 9213-9218.

44. Rommel C, Bodine SC, Clarke BA, Rossman R, Nunez L, et al. (2001) Mediation of IGF-1-induced skeletal myotube hypertrophy by $\mathrm{PI}(3) \mathrm{K} / \mathrm{Akt} / \mathrm{mTOR}$ and $\mathrm{PI}(3) \mathrm{K} / \mathrm{Akt} / \mathrm{GSK} 3$ pathways. Nat Cell Biol 3: 1009-1013.

45. De Tullio R, Stifanese R, Salamino F, Pontremoli S, Melloni E (2003) Characterization of a new p94-like calpain form in human lymphocytes. Biochem J 375: 689-696.

46. Konig N, Raynaud F, Feane H, Durand M, Mestre-Frances N, et al. (2003) Calpain 3 is expressed in astrocytes of rat and Microcebus brain. J Chem Neuroanat 25: 129-136.

47. Sorimachi H, Imajoh-Ohmi S, Emori Y, Kawasaki H, Ohno S, et al. (1989) Molecular cloning of a novel mammalian calcium-dependent protease distinct from both $\mathrm{m}$ - and mutypes. Specific expression of the mRNA in skeletal muscle. J Biol Chem 264: 20106-20111.

48. Goll DE, Thompson VF, Li H, Wei W, Cong J (2003) The calpain system. Physiol Rev 83: 731-801

49. Goll DE, Neti G, Mares SW, Thompson VF (2008) Myofibrillar protein turnover the proteasome and the calpains. J Anim Sci 86: E19-35

50. Davies PJ, Wallach D, Willingham MC, Pastan I, Yamaguchi M, et al. (1978) Filamin-actin interaction. Dissociation of binding from gelation by $\mathrm{Ca2+}$ activated proteolysis. J Biol Chem 253: 4036-4042.

51. Dayton WR, Goll DE, Zeece MG, Robson RM, Reville WJ (1976) A Ca2+activated protease possibly involved in myofibrillar protein turnover. Purification from porcine muscle. Biochemistry 15: 2150-2158.

52. Bardsley RG, Allcock SM, Dawson JM, Dumelow NW, Higgins JA, et al. (1992) Effect of beta-agonists on expression of calpain and calpastatin activity in skeletal muscle. Biochimie 74: 267-273.

53. Parr T, Bardsley RG, Gilmour RS, Buttery PJ (1992) Changes in calpain and calpastatin mRNA induced by beta-adrenergic stimulation of bovine skeletal muscle. Eur J Biochem 208: 333-339.

54. Yimlamai T, Dodd SL, Borst SE, Park S (2005) Clenbuterol induces musclespecific attenuation of atrophy through effects on the ubiquitin-proteasome pathway. J Appl Physiol 99: 71-80.

55. Bakker AJ, Head SI, Wareham AC, Stephenson DG (1998) Effect of clenbutero on sarcoplasmic reticulum function in single skinned mammalian skeletal muscle fibers. Am J Physiol 274: C1718-1726.

56. Prakash YS, van der Heijden HF, Gallant EM, Sieck GC (1999) Effect of betaadrenoceptor activation on $[\mathrm{Ca} 2+]$ r regulation in murine skeletal myotubes. Am J Physiol 276: C1038-1045.

57. Beermann DH, Butler WR, Hogue DE, Fishell VK, Dalrymple RH, et al. (1987) Cimaterol-induced muscle hypertrophy and altered endocrine status in lambs. J Anim Sci 65: 1514-1524.

58. Bell AW, Bauman DE, Beermann DH, Harrell RJ (1998) Nutrition, development and efficacy of growth modifiers in livestock species. J Nutr 128: 360S-363S.

59. Hamby PL, Stouffer JR, Smith SB (1986) Muscle metabolism and real-time ultrasound measurement of muscle and subcutaneous adipose tissue growth in lambs fed diets containing a betaagonist. J Anim Sci 63: 1410-1417. 
Citation: Douillard A (2011) Skeletal and Cardiac Muscle Ergogenics and Side Effects of Clenbuterol Treatment. J Sport Medic Doping Studie S1:001. doi:10.4172/2161-0673.S1-001

Page 6 of 7

60. Hoey AJ, Reich MM, Davis G, Shorthose R, Sillence MN (1995) Beta 2-adrenoceptor densities do not correlate with growth, carcass quality, or meat quality in cattle. J Anim Sci 73: 3281-3286

61. Hulot F, Ouhayoun, J., Manoucheri, M (1996) Effect of clenbuterol on productive performance, body composition and muscle biochemistry in the rabbit. Meat Sci 42: 457-464

62. Koohmaraie M, Shackelford SD, Muggli-Cockett NE, Stone RT (1991) Effect of the betaadrenergic agonist L644,969 on muscle growth, endogenous proteinase activities, and postmortem proteolysis in wether lambs. J Anim Sci 69: 4823-4835

63. Mersmann HJ (1998) Overview of the effects of beta-adrenergic receptor agonists on animal growth including mechanisms of action. J Anim Sci 76: 160172 .

64. Miller MF, Garcia DK, Coleman ME, Ekeren PA, Lunt DK, et al. (1988) Adipose tissue, longissimus muscle and anterior pituitary growth and function in clenbuterol-fed heifers. J Anim Sci 66: 12-20.

65. Reeds PJ, Hay SM, Dorwood PM, Palmer RM (1986) Stimulation of muscle growth by clenbuterol: lack of effect on muscle protein biosynthesis. $\mathrm{Br} \mathrm{J}$ Nutr 56: $249-258$

66. Ricks CA, Dalrymphe RH, Baker PK, Ingle DL (1984) Use of a $\beta$-agonist to alter fat and muscle deposition in steers. J Anim Sci 59:1247-1255.

67. Schiavetta AM, Miller MF, Lunt DK, Davis SK, Smith SB (1990) Adipose tissue cellularity and muscle growth in young steers fed the beta-adrenergic agonist clenbuterol for 50 days and after 78 days of withdrawal. J Anim Sci 68: 3614 3623.

68. Arch JR, Ainsworth AT, Cawthorne MA, Piercy V, Sennitt MV, et al. (1984) Atypical beta-adrenoceptor on brown adipocytes as target for anti-obesity drugs. Nature 309: 163-165.

69. Arch JR, Kaumann AJ (1993) Beta 3 and atypical beta-adrenoceptors. Med Res Rev 13: 663-729.

70. Belahsen R, Deshaies $Y$ (1992) Modulation of lipoprotein lipase activity in the rat by the beta 2-adrenergic agonist clenbuterol. Can J Physiol Pharmacol 70 : 1555-1562.

71. Bergen WG, Merkel RA (1991) Body composition of animals treated with partitioning agents: implications for human health. FASEB J 5: 2951-2957.

72. Blum JW, Flueckiger N (1988) Early metabolic and endocrine effects of perorally administered beta-adrenoceptor agonists in calves. Eur J Pharmacol 151: 177-187.

73. MacRae JC, Skene PA, Connell A, Buchan V, Lobley GE (1988) The action of the betaagonist clenbuterol on protein and energy metabolism in fattening wether lambs. Br J Nutr 59: 457-465.

74. Rothwell NJ, Stock MJ (1985) Modification of body composition by clenbutero in normal and dystrophic (mdx) mice. Biosci Rep 5: 755-760.

75. Rothwell NJ, Stock MJ, Sudera DK (1987) Changes in tissue blood flow and beta-receptor density of skeletal muscle in rats treated with the beta2adrenoceptor agonist clenbuterol. Br J Pharmacol 90: 601-607.

76. Mills S (2000) Beta-adrenergic receptor subtypes mediating lipolysis in porcine adipocytes. Studies with BRL-37344, a putative beta3-adrenergic agonist. Comp Biochem Physiol C Toxicol Pharmacol 126: 11-20

77. Cartana J, Segues T, Yebras M, Rothwell NJ, Stock MJ (1994) Anabolic effects of clenbuterol after long-term treatment and withdrawal in t the rat. Metabolism 43: 1086-1092.

78. Burniston JG, Tan LB, Goldspink DF (2005) Beta2-Adrenergic receptor stimulation in vivo induces apoptosis in the rat heart and soleus muscle. J Appl Physiol 98:1379-1386.

79. Kerr JF, Wyllie AH, Currie AR (1972) Apoptosis: a basic biological phenomenon with wideranging implications in tissue kinetics. Br J Cancer 26: 239-257.

80. Burniston JG, Ng Y, Clark WA, Colyer J, Tan LB, et al. (2002) Myotoxic effects of clenbuterol in the rat heart and soleus muscle. J Appl Physiol 93: 1824-1832.

81. Burniston JG, Chester N, Clark WA, Tan LB, Goldspink DF (2005) Dosedependent apoptotic and necrotic myocyte death induced by the beta2adrenergic receptor agonist, clenbuterol. Muscle Nerve 32: 767-774.

82. Petrou M, Wynne DG, Boheler KR, Yacoub MH (1995) Clenbuterol induces hypertrophy of the latissimus dorsi muscle and heart in the rat with molecula and phenotypic changes. Circulation 92: ॥483-489.

83. Jeppson $\mathrm{DH}$ (1986) The competitive health care marketplace: bringing new challenges to a changing field. Health Care Strateg Manage 4: 10-13.

84. Leone M, Albanese J, Martin C (2002) Positive inotropic stimulation. Curr Opin Crit Care 8: 395-403.

85. Sleeper MM, Kearns CF, McKeever KH (2002) Chronic clenbuterol administration negatively alters cardiac function. Med Sci Sports Exerc 34: 643-650.

86. Kendall MJ, Tse WY, Head A (1993) The treatment of elderly hypertensive patients. J Clin Pharm Ther 18: 9-14.

87. Duncan ND, Williams DA, Lynch GS (2000) Deleterious effects of chronic clenbuterol treatment on endurance and sprint exercise performance in rats. Clin Sci (Lond) 98: 339-347.

88. Duncan ND, Williams DA, Lynch GS (1998) Adaptations in rat skeletal muscle following long-term resistance exercise training. Eur J Appl Physiol Occup Physiol 77: 372-378.

89. Soppa GK, Smolenski RT, Latif N, Yuen AH, Malik A, et al. (2005) Effects of chronic administration of clenbuterol on function and metabolism of adult rat cardiac muscle. Am J Physiol Heart Circ Physiol 288: H1468-476.

90. Tsuneyoshi H, Oriyanhan W, Kanemitsu H, Shiina R, Nishina T, et al. (2005) Does the beta2-agonist clenbuterol help to maintain myocardial potential to recover during mechanical unloading? Circulation 112: 151-156.

91. Bricout VA, Serrurier BD, Bigard AX (2004) Clenbuterol treatment affects myosin heavy chain isoforms and MyoD content similarly in intact and regenerated soleus muscles. Acta Physiol Scand 180: 271-280.

92. Hayes A, Williams DA (1994) Long-term clenbuterol administration alters the isometric contractile properties of skeletal muscle from normal and dystrophindeficient mdx mice. Clin Exp Pharmacol Physiol 21: 757-765.

93. Maltin CA, Delday MI, Reeds PJ (1986) The effect of a growth promoting drug clenbuterol, on fibre frequency and area in hind limb muscles from young male rats. Biosci Rep 6: 293-299.

94. Palmer RM, Delday MI, McMillan DN, Noble BS, Bain P, et al. (1990) Effects of the cyclo-oxygenase inhibitor, fenbufen, on clenbuterol-induced hypertrophy of cardiac and skeletal muscle of rats. Br J Pharmacol 101: 835-838.

95. Zeman RJ, Ludemann R, Etlinger JD (1987) Clenbuterol, a beta 2-agonist, retards atrophy in denervated muscles. Am J Physiol 252: E152-155.

96. Lynch GS, Hayes A, Campbell SP, Williams DA (1996) Effects of beta 2-agonis administration and exercise on contractile activation of skeletal muscle fibers. Appl Physiol 81: 1610-1618.

97. d'Albis A, Couteaux R, Janmot C, Mira JC (1989) Myosin isoform transitions in regeneration of fast and slow muscles during postnatal development of the rat. Dev Biol 135: 320-325.

98. Pette D, Peuker H, Staron RS (1999) The impact of biochemical methods for single muscle fibre analysis. Acta Physiol Scand 166: 261-277.

99. Caiozzo VJ, Baker MJ, Baldwin KM (1998) Novel transitions in MHC isoforms: separate and combined effects of thyroid hormone and mechanical unloading J Appl Physiol 85: 2237-2248.

100.Green HJ, Klug GA, Reichmann H, Seedorf U, Wiehrer W, et al. (1984) Exercise-induced fibre type transitions with regard to myosin, parvalbumin and sarcoplasmic reticulum in muscles of the rat. Pflugers Arch 400: 432-438.

101.Lynch GS, Duncan ND, Campbell SP, Williams DA (1995) Endurance training effects on the contractile activation characteristics of single muscle fibres from the rat diaphragm. Clin Exp Pharmacol Physiol 22: 430-437.

102. Chin ER, Olson EN, Richardson JA, Yang Q, Humphries C, et al. (1998) A calcineurin-dependent transcriptional pathway controls skeletal muscle fiber type. Genes Dev 12: 2499-2509.

103. Naya FJ, Mercer B, Shelton J, Richardson JA, Williams RS, et al. (2000) Stimulation of slow skeletal muscle fiber gene expression by calcineurin in vivo. J Biol Chem 275: 4545-4548.

104. McKinsey TA, Zhang CL, Olson EN (2000) Activation of the myocyte enhancer factor-2 transcription factor by calcium/calmodulin-dependent protein kinasestimulated binding of 14-3-3 to histone deacetylase 5. Proc Natl Acad Sci U S A 97: 14400-14405. 
Citation: Douillard A (2011) Skeletal and Cardiac Muscle Ergogenics and Side Effects of Clenbuterol Treatment. J Sport Medic Doping Studie S1:001. doi:10.4172/2161-0673.S1-001

105. Lin J, Wu H, Tarr PT, Zhang CY, Wu Z, et al. (2002) Transcriptional coactivator PGC-1 alpha drives the formation of slow-twitch muscle fibres. Nature 418: 797-801.

106. Lunde IG, Ekmark M, Rana ZA, Buonanno A, Gundersen K (2007) PPARdelta expression is influenced by muscle activity and induces slow muscle properties in adult rat muscles after somatic gene transfer. J Physiol 582: 1277-1287.

107. Murgia M, Serrano AL, Calabria E, Pallafacchina G, Lomo T, et al. (2000) Ras is involved in nerve-activity-dependent regulation of muscle genes. Nat Cell Biol 2: 142-147.

108. Grifone R, Laclef C, Spitz F, Lopez S, Demignon J, et al. (2004) Six1 and Eya1 expression can reprogram adult muscle from the slow-twitch phenotype into the fast-twitch phenotype. Mol Cell Biol 24: 6253-6267.

109. Richard AF, Demignon J, Sakakibara I, Pujol J, Favier M, et al. Genesis of muscle fiber-type diversity during mouse embryogenesis relies on Six1 and Six4 gene expression. Dev Biol 359: 303-320.

110. Yang YT, McElligott MA (1989) Multiple actions of beta-adrenergic agonists on skeletal muscle and adipose tissue. Biochem J 261: 1-10.

111. Claeys MC, Mulvaney DR, McCarthy FD, Gore MT, Marple DN, et al. (1989) Skeletal muscle protein synthesis and growth hormone secretion in young lambs treated with clenbuterol. J Anim Sci 67: 2245-2254.

112. Inkster JE, Hovell FD, Kyle DJ, Brown DS, Lobley GE (1989) The effect of clenbuterol on basal protein turnover and endogenous nitrogen loss of sheep. Br J Nutr 62: 285-296.

113. Benson DW, Foley-Nelson T, Chance WT, Zhang FS, James JH, et al. (1991) Decreased myofibrillar protein breakdown following treatment with clenbuterol. J Surg Res 50: 1-5.

114. Bohorov O, Buttery PJ, Correia JH, Soar JB (1987) The effect of the beta-2 adrenergic agonist clenbuterol or implantation with oestradiol plus trenbolone acetate on protein metabolism in wether lambs. Br J Nutr 57: 99-107.

115. Wang SY, Beermann DH (1988) Reduced calcium-dependent proteinase activity in cimaterol-induced muscle hypertrophy in lambs. J Anim Sci 66: 2545-2550.

116. Kline WO, Panaro FJ, Yang H, Bodine SC (2007) Rapamycin inhibits the growth and muscle-sparing effects of clenbuterol. J Appl Physiol 102: 740-747.

117. Shi H, Zeng C, Ricome A, Hannon KM, Grant AL, et al. (2007) Extracellular signalregulated kinase pathway is differentially involved in beta-agonistinduced hypertrophy in slow and fast muscles. Am J Physiol Cell Physiol 292: C1681-1689.

118. Hill RA, Hoey AJ, Sillence MN (1998) Functional activity of antibodies at the bovine beta2- adrenoceptor. J Anim Sci 76: 1651-1661.

119. Sillence MN, Matthews ML, Badran TW, Pegg GG (2000) Effects of clenbutero on growth in underfed cattle. Australian Journal Agriculture Research 51: 401 406.

120. Maltin CA, Delday MI, Hay SM, Smith FG, Lobley GE, et al. (1987) The effect of the anabolic agent, clenbuterol, on overloaded rat skeletal muscle. Biosci Rep 7: 143-149.

121. Rehfeldt C, Schadereit R, Weikard R, Reichel K (1997) Effect of clenbuterol on growth, carcase and skeletal muscle characteristics in broiler chickens. B Poult Sci 38: 366-373.

122. Sharma AK, Lee YB, Murray JD (1997) The response of transgenic mice to beta-adrenergic agonist administration is different from that of normal mice. $J$ Anim Sci 75: 2092-2099.

123. Spann C, Winter ME (1995) Effect of clenbuterol on athletic performance. Ann Pharmacother 29: 75-77.

124. Ingalls CP, Barnes WS, Smith SB (1996) Interaction between clenbuterol and run training: effects on exercise performance and MLC isoform content. J App Physiol 80: 795-801.

125. Dodd SL, Powers SK, Vrabas IS, Criswell D, Stetson S, et al. (1996) Effects of clenbuterol on contractile and biochemical properties of skeletal muscle. Med Sci Sports Exerc 28: 669-676.

126. Torgan CE, Kraus WE (1996) Regulation of type II adenylyl cyclase mRNA in rabbit skeletal muscle by chronic motor nerve pacing. Am J Physiol 271: E253-260.

127. Mounier R, Cavalie H, Lac G, Clottes E (2007) Molecular impact of clenbutero and isometric strength training on rat EDL muscles. Pflugers Arch 453: 497 507.

128. Pellegrino MA, D’Antona G, Bortolotto S, Boschi F, Pastoris O, et al. (2004) Clenbuterol antagonizes glucocorticoid-induced atrophy and fibre type transformation in mice. Exp Physiol 89: 89-100.

129. Polla B, Cappelli V, Morello F, Pellegrino MA, Boschi F, et al. (2001) Effects of the beta(2)-agonist clenbuterol on respiratory and limb muscles of weaning rats. Am J Physiol Regul Integr Comp Physiol 280: R862-869.

130. Torgan CE, Brozinick JT, Banks EA, Cortez MY, Wilcox RE, et al. (1993) Exercise training and clenbuterol reduce insulin resistance of obese Zucker rats. Am J Physiol 264: E373-379.

131. Cavalié $\mathrm{H}$, Mounier R, Clottes $\mathrm{E}$, Bricout $\mathrm{V}$, Lac G (2004) Clenbuterol treatment differently affects muscle in exercised or sedentary rats. J Exer Physiol 7: 111 120. 